\title{
Digteren Goldschmidt og Grundtvig
}

\author{
Et opgør om Nationalitet og Danskhed
}

\section{Af Morten Bredsdorff}

»Hr. Grundtvig satte mig i Band火.

Goldschmidt, 1853.

\section{I}

Det er velkendt, at da den unge redaktør af det politiske vittighedsblad "Corsaren«, M. A. Goldschmidt, gav sig i kast med Søren Kierkegaard, fik bladets i vore øjne ret ubetydelige stiklerier og ubehjælpsomme karikaturtegninger vidtrækkende følger $i$ den store ensomme tænkers forfatterskab. ${ }^{1}$

"Corsarens« forhold til Grundtvig påkalder ikke den samme interesse. De spredte hentydninger til »den gamle nordiske Ørn Grundtvig " (nr. 384) angår især hans højstemte nordiske stil, som bladet finder komisk, og hans nationale iver. Nr. 12 bringer en Grundtvig-parodi "Aabent Brev mod de Tydske Kættere, fundet paa Vartou Loft«. Nr. 188 fornøjer læserne med et lille "Optrin af Grundtvigs Kæmpeliv«. Digteren står ved vejbommen til »Danskhedens Borg « og tordner - i Poul Møllers himmelbrevstil - mod alt udansk: "Vagt maae der holdes, ud maae der feies, slaaes maae der i Hovedet, naar Nationaliteten skal holdes reen!« Hvorefter Nathanson (Berl. Tid.) afvises på grund af sit uheldige -son, Boetius for sit latinske navn og Stemann (statsministeren) for sit tyske dobbelte $\mathrm{n}$. Da Christian VIII viser sig tiltaler Grundtvig ham på godt nordisk som »Christiern «, kommer så i tanker om, at han er en »Oldenburger«, men bukker alligevel ærbødigt og hæver bommen for majestæten. I en lille afhandling om det danske sprog indrømmer bladet, at det gerne vil kæmpe videre for »hvad Grundtvig mindre forstaaeligt og mindre forstaaet har raabt i snart 50 Aar «, nemlig at danskerne bør vogte sig for at ødelægge deres gode sprog 
med tyske og franske brokker (nr. 215). Vittighederne er oftest i denne stil: Grundtvig har i Dansk Samfund holdt en tale, hvori han fraråder sine tilhørere at gå i teatret, da det er stygt at se folk stå på scenen og gøre sig til nar. "Corsaren« vil gerne fraråde sine læsere at gå i Dansk Samfund - af samme grund!

De øvrige hilsner til Grundtvig er på lignende vis præget af humoristisk drilleri af den gamle digter med det løjerlige sprog, der - hedder det i nr. 367, (hvor Goldschmidt dog var gået af) har smittet af på sønnen Svend Grundtvigs udgave af »Kjæmpeviserne«. Endnu er Grundtvig ikke nogen egentlig politisk personlighed, og det er fortrinsvis dem »Corsaren « tager under behandling.

Det blev anderledes i Goldschmidts næste tidsskrift, det seriøse måneds- (senere uge-) blad »Nord og Syd «.

- - -

Næsten lige fra sin begyndelse i 1840 havde "Corsaren « bragt artikler om den slesvig-holstenske sag, 1840ernes brændende spørgsmål. Bladet havde klart taget stilling for Helstaten, men med sin egen begrundelse. Det kunne ikke som de Nationalliberale støtte sig til Enevælden, som det af al magt bekæmpede, men krævede vidtgående indførelse af lokalt selvstyre. Overfor den voksende skandinaviske studenterbevægelse forholdt det sig skeptisk med et skarpt øre for de mange romantiske drømmerier og højstemte skåltaler. »Corsaren « nr. 225 bringer i 1844 et referat af det store nationale møde på »Høiskamling «, hvor den unge Goldschmidt rakte slesvigerne hånden sammen med Grundtvig, Laurids Skau, P. Hiort Lorenzen og Carl Ploug. Goldschmidts korte tale refereres, dog uden at nævne hans navn. ${ }^{2}$

I 1846 opgav Goldschmidt »Corsaren«, træt af de evindelige besværligheder med politi og censur. Selv var han ved en højesteretsdom i 1843 på grund af fire beslaglagte artikler blevet sat under livsvarig censur og havde derfor jævnlig måttet skifte "stråmænd « som formelle redaktører af bladet. Men han havde tjent ret godt på det; nu solgte han det, og for pengene drog han i efteråret $1846 \mathrm{ud}$ på sin store europæiske dannelsesrejse »for at blive af med Vittigheden og lære Noget. Jeg var da 27 Aar og havde udgivet »Corsaren « i 6 Aar «. ${ }^{3}$

Med stærke indtryk af det politisk urolige Europa på vej mod februar- og martsrevolutionerne i 1848 og med en langt dybere indsigt $i$ udenlandske forhold end nogen anden dansk journalist $\mathbf{i}$ 
dette tidehverv, vendte Goldschmidt hjem i eftersomren 1847. Rejsen havde ført ham gennem Tyskland, Østrig, Italien, (Frankrig havde han tidligere besøgt) og Schweiz, og med sit livfulde og åbne væsen var det lykkedes ham at komme i personlig forbindelse med mange af tidens forfattere og politikere. De varigste virkninger $i$ hans liv fik hans oplevelser i den lille alperepublik. Her fik han sine hidtil noget svævende tanker om den dansk-tyske Helstat solidt undermuret gennem stærke indtryk af den schweiziske statsordning. Han nåede Genève just som den farlige »Særforbundskrig « mellem de 7 katolske, indreschweiziske og de øvrige liberale kantoner nærmede sig sin i hovedsagen ublodige og lykkelige afslutning. Nye forfatninger skulle udarbejdes og vedtages af de enkelte kantoners »tingmøder « som forudsætning for den fællesforfatning, der - vedtaget året efter - skulle omdanne det hidtil ret løse statsforbund til en moderne forbundsstat med vidtgående frihed for de enkelte kantoner til at styre egne sager. Her blæste en skarp og frisk bjergluft, vidt forskellig fra den indeklemte atmosfære i det gamle kongedømme ved Østersøen. I parlamentet i Bern hørte han politiske indlæg på tysk og fransk i stor fordragelighed, ministre og ledende politikere kunne på værtshus eller bjergture mødes med arbejdere og bønder. Det hele virkede på den danske iagttager som et politisk modent folks dygtige arbejde på at løse konflikter mellem sproglige og religiøse modsætninger, der indenfor statens rammer havde truet med krig. Han syntes at genkende de vanskeligheder, som var opstået ved den hjemlige Helstats sydlige grænse, hvor den tysktalende befolkning i Holsten og Sydslesvig havde vakt uro ved at stille politiske frihedskrav til den enevældige konge. »Særforbundskrigen" havde truet alperepublikens enhed fuldt så meget som et muligt slesvig-holstensk oprør ville kunne gøre hjemme. Her var striden løst ved politisk klogskab og demokratisk fordragelighed. Det måtte kunne lade sig gøre også i Danmark.

I Goldschmidts i 1847 grundlagte nye tidsskrift "Nord og Syd" bragte han allerede i 2. nr. en ret udførlig fremstilling af Schweiz' historie. ${ }^{4}$ Året efter kom den store artikel »Føderativstaten «. ${ }^{5}$ »I Schweiz vare Cantonerne vel oprindelig, for 700 Aar siden, souveraine Smaastater, der sluttede Alliance, men de havde, lidt efter lidt, opgivet en betydelig Deel af deres Souverainitet og overgivet dem til det Hele, Schweizerstaten, og således bragt Delenes Frihed i Harmoni med det Heles Magt og Myndighed«. Han betegner 
schweizerne som »de eneste frie Mænd i Europa«, »det er som en ny Menneskerace, med en Friskhed og Naturlighed, jeg aldrig før har seet «. ${ }^{6}$ Til sin tyske ven, dr. Arnold Ruge, skrev han: "Die Majestät des lebendigen Lebens ist mir aufgegangen«. "De nye Ideer have grebet mig som en Stormvind «.?

Seks år senere, da han for anden gang forlod det politiske liv, skrev Goldschmidt i »Et Tilbageblik « nogle bitre linier: »Intet har i verdslig Henseende skadet mig mere, end hvad jeg lærte i Schweiz. Uden det vilde jeg formodentlig aldrig have lagt Mærke til, at der i det danske Monarki var to Nationaliteter, der ligesom hist kunde foreenes $i$ en Føderativstat, som blev sund og stærk ved Landdage og Communalforfatninger. - Derfor satte $\mathrm{Hr}$. Grundtvig mig $i$ Band, og de Andre skjældte mig ud, ja, hvad have de ikke gjort! Derfor har jeg heller aldrig bragt det til Noget i Danmark «. ${ }^{8}$

\section{II}

»Nord og Syd «, nr. 1, ${ }^{9}$ begyndte med en udforlig programerklæring, skrevet af Goldschmidt, der på grund af den "livsvarige censur« ikke er nævnt som redaktør. (Censuren blev hævet ved et amnestireskript undertegnet af Frederik VII 24/1 1848 umiddelbart efter hans tronbestigelse). Han tager klart afstand fra den døende enevælde, men også fra den »ideløse Opposition« som de Nationalliberale har drevet, ikke mindst efter at de nu i anledning af nationalitetsrøret har søgt tilflugt hos absolutismen. »Hvo skulde $i$ et saadant Virvar føre Folket til Frihed? « De har bidt sig fast i spørgsmålet om skattebevillingsret og konstitution, som om Friheden var et juridisk spørgsmål. »Den politiske Ulykke bestaaer ikke i at have en despotisk Regering, men i at være et sløvt Folk«. Efter en kort historisk oversigt over frihedstankernes oprindelse fra kristendommen, fastslår redaktøren til slut, at hans blad hverken vil kæmpe for en revolutionær omvæltning, som i Frankrig, ejheller tilråde fortvivlet flugt, som i Tyskland. Han vil »slutte sig til det Nærværende, benytte det Gode, man finder deri, og stadig stræbe til Opnaaelsen af flere Goder «. Oplysning, især politisk oplysning, er hvad folket har brug for, selvtilliden skal vækkes, sådan som han selv har oplevet det i Genéve og Bern; derfor vil skriftet stå frit til alle sider og bringe inden- og udenlandsk oplysning; og netop derfor er et tidsskrift nødvendigt, »da den udenlandske Politik ikke er tilladt i Dag- og Ugeblade«. På baggrund af en ret solid politisk 
orientering og personlige indtryk af det europæiske demokratis hjemland træder Goldschmidt, modnet og afklaret, påny ind på den danske politiske scene. Her hører man hans røst under hele Treårskrigen og først $\mathrm{i}$ de følgende bevægede år fra 1850 aftager det politiske stof $i$ »Nord og Syd" gradvis og erstattes af den fortløbende udsendelse af Goldschmidts store roman »Hjemløs« og litterære og kulturhistoriske afhandlinger, indtil tidsskriftet i 1859 gik ind.

Ved Forfatningsreskriptet af 28. januar 1848 »sank Enevælden stille og modstandsløst i sin Grav. Selv de, der før havde været dens stærkeste Forsvarere, glædede sig nu over "Frihed « eller tav i alt Fald stille.$^{10}$ Dermed var sluserne åbnet for en livlig offentlig debat, hvori det nationale spørgsmål hurtigt kom til at indtage førstepladsen. Og mens næsten hele pressen fra »Fædrelandet« til "Kjøbenhavnsposten « sluttede op om det såkaldte Schouw-Clausenske forslag, der skitserede en meget aristokratisk forfatning, der kun ville give magten til den intelligente middelstand og forsøgte at løse det nationale problem ved en fællesforfatning for Danmark og Slesvig, altså »Ejderstaten«, mens Holsten skulle have sin egen forfatning, var Goldschmidt den eneste, der kraftigt angreb denne udvej. Med grelle exempler fra Frankrigs nyeste politiske historie viste han de vilkår, friheden kunne vente sig under en sådan aristokratisk forfatning. Han forudså allerede nu, at arvespørgsmålet efter Frederik VII, den sidste Oldenborger, kunne få afgørende følger for den slesvig-holstenske strid. »En Gang i Tiden kan der ved Tronskifte true Danmark en virkelig Fare, trods alle Forsigtighedsregler. Der behøves da megen Fasthed, megen Ro og Bevidsthed. Er der tidligere begået Fejl, lærer man af dem at indrette sig for Fremtiden«. Regeringen bør derfor benytte tiden til at forberede folket. »Den kan gøre Frederik d. 7.s Tid til en virkelig Forberedelsestid, hvis Maal ikke skal naaes i Hast, til Maj, men hvis Opgave er at lade alle Spirer vokse og modnes. Constitutionen forsvinder ikke i Mellemtiden. Løftet herom er gaaet over i det danske Blod; man beder Kongen gaae fremad paa den Reformbane, han har betraadt, og hvorpaa vi allerede nu aande lettere og friere; man andrager paa Pressefrihed, Associationsfrihed, Almenvæbning, Udvikling af Kommune- og Sognefrihed, Jurydomstole og en Udvidelse af Valgloven for de raadgivende Stænder «. I Slesvig og Holsten vil sådanne foranstaltninger vække velvilje og overbevise 
om, at forbindelsen med Danmark er velgørende. Men sagen har hast, frihedsbevægelsen skrider frem i Frankrig, dens ideer breder sig $\mathrm{i}$ Tyskland. »Og hvor faldt Holsten hen ved en tysk Revolution eller Forbundsreform? - Tiden kan ikke vedblive at staa stille, Tyskland maae udvikle sig - hvad blev dets (Holstens) Skæbne, naar det ikke ved Friheden var knyttet til Danmark? « Han slutter med at henvise til det demokratiske Schweiz, hvor kantoner af blandet nationalitet og sprog lever fredeligt sammen under kantonsforfatninger og en fælles føderativ forfatning. ${ }^{11}$

Det store Casinomøde i København den 11. marts var sammenkaldt af de ledende nationalliberale, N. L. Hvidt, H. N. Clausen, Chr. Flor, Carl Ploug, Orla Lehmann, A. F. Krieger og A. F. Tscherning for i forventning om afgørende skridt fra det slesvigholstenske parti at styrke bevidstheden om nødvendigheden af "Danmarks og Slesvigs konstitutionelle Forening «, og her fik Goldschmidt lejlighed til at vise sit eget ansigt. De ca. 2300 tilstedeværende borgere lyttede med begejstring til Lehmann, der reducerede det indrepolitiske spørgsmål om gennemførelsen af fuld konstitutionel frihed til noget, der kunne gennemføres med god vilje. "Den egentlige store Vanskelighed, det erkender alle, ligger i den statsretlige Forvikling; den egentlige Knude, som, hvis den ej kan løses, maa hugges over, den er Slesvigs Stilling. - Derfor stævne vi alle gode danske Mænd derhen, hvor Danmarks Skæbne skal afgiøres; derfor have vi til vort Løsen valgt »Slesvigs konstitutionelle Forening med Danmark««. Clausen føjede til, at Slesvigholstenerne kun var blevet stærke ved vor Svaghed. "Danmark har her ikke at giøre med nogen fjendtlig Overmagt. Thi, at der fra det tyske Forbunds Side skulde være at befrygte nogen Indblanding i de slesvigske Forhold, som jo dog ikke vedkommer Forbundet i fjærneste Maade, kan dog ikke gjælde for andet end Spøgelsesfrygt! $\aleph^{12}$

Da dirigenten (Hvidt) spurgte, om der endnu var nogen, som ikke var overbevist, lød et tordnende Nej fra forsamlingen. Dog begærende den kendte skolelærer Rasmus Sørensen ordet for at protestere mod nationalt stemningsmageri og forsøg på »at inddrage Folkene i forældede Nationalitetsstridigheder «. Han blev afbrudt af larm og hyssen og af dirigenten karakteriseret som »en forvirret skolelærer«. Så banede den 28-årige Goldschmidt sig vej til talerstolen og begyndte under stigende larm og uro at tale. Ifølge sin 
egen skildring af mødet indledte han, lidt højstemt, med at udtrykke, at han tog sig hverken bifald eller mishag nær, blot hans ord måtte finde medhold »hos Retfærdigheden, der lever evigt«. Indtrængende advarede han mod at tvinge regeringen til, imod dens egne tilsagn, at ophæve forbindelsen mellem Slesvig og Holsten. Men selv om konge og folk skulle kunne enes herom, ville det være uretfærdigt "at indlemme Slesvig i en konstitutionel forbindelse med Danmark uden at sporge det slesvigske Folk! "Hermed blev denne tanke første gang bragt offentlig frem, men samtidig blev han rigtignok også afbrudt af dirigenten og af høje protestråb fra forsamlingen. Det lykkedes ham endnu engang at råbe den op: »I Frihedens og Retfærdighedens Navn protesterer jeg imod, at Slesvig uden at adspørges tvinges til en Forening med Danmark!« Derpå greb Tscherning ordet og samlede mødets stemning i en kort sætning: "Man kan ikke spørge Slesvig; thi Slesvigholstenerne svarer. Er Slesvig genstridigt, maa det tvinges! « Under larmende tilslutning blev mødet hævet - »fordi Klokken var ti«.

På den næste dags store møde i Håndværkerdannelsesforeningen hørte Goldschmidt første gang »Ordet national blive brugt til at betegne Noget i vort politiske Liv, hvorfra jeg var forskjellig. Jeg forstod ikke Ordet straks i hele den næsten frygtelige Betydning, det senere skulle faae«. I sin egen korte tale henstillede han, at man opgav navnene »National og Antinational«. »Thi derved at et Parti udelukkende kalder sig nationalt, indtager det forud den offentlige Mening for sig, og prisgiver Modstanderne til den almindelige Uvillie «. ${ }^{13}$ Skønt dette møde oprindelig var indvarslet af håndværkere og mindre handlende for at stille krav om udvidet valgret, lykkedes det også her Orla Lehmann at vække den nationale begejstring og Goldschmidts advarende ord faldt igen til jorden. ${ }^{14}$

\section{III}

Da fik hans tanker en uventet håndsrækning fra Grundtvig. Den 14. marts, et par dage efter de forannævnte møder, talte Grundtvig i Den slesvigske Hjelpeforening, der nylig var stiftet (en slags forløber for Sprog- og Skoleforeningerne).

Grundtvig var netop ved at lægge sidste hånd på det første nr. af sit nye ugeblad »Danskeren «, en slags talerstol, hvorfra han selv og hans nærmeste tilhængere i de følgende år tog livlig del i den 
hastigt voksende debat om folkestyre, grundlov og det slesvig-holstenske spørgsmål. »Danskerens« 1. nr. udkom den 22. marts 1848 og i åbningsartiklen skrev han sit program: "Af Troen udspringer Haabet, og naar det Danske Folk, saa at sige eenstemmigt, vægrer sig ved at opoffre Danmarks Rige for Slesvig-Holsten, for hele Tyskland, ja, for hele Verden, da skal intet andet bringe mit Danske Haab til at glippe, hvor urimeligt dette Haab end synes for de Fleste«.

"Danskerens « nr. 6, 26/4, bringer hans eget referat af talen i Den slesvigske Hjelpeforening. Han indleder med at sige, at tiden fra Wienerkongressens dage til nu har været stille, "Metternichs und weiter nichts«. Men nu er tiden blevet »dygtig bevæget, og det sørger jeg ingenlunde over, thi af to onde Ting skal man vælge den mindste, og Frihed uden Orden har, i det mindste siden jeg først saae Engeland, altid været et mindre Onde end Orden uden Frihed. - Kiendsgerninger er, som Engelskmanden meget rigtig siger, haardnakkede Krabater, og en saadan haardnakket Kiendsgerning er det, at Kongeriget Danmark, hvorvidt det saa end gik i gamle Dage, nu dog ikke gaaer en Fodsbred langere end til Grændsen af Hertugdømmet Slesvig, og det Danske Land gaaer i det allerhøieste kun saa vidt, som man taler Dansk, og igrunden ikke længere, end man vil blive ved at tale Dansk, altsaa til etsteds, man veed ikke hvor, midt inde i Hertugdømmet Slesvig «. Da Holsten tilhører det tyske forbund, men Slesvig står udenfor, må vi overveje »hvad vi kan giøre med Rette og rimeligvis med Held for at hævde vort gamle Krav paa hele Slesvig, og hævde Danskens utabelige Ret til i Hertugdømmet Slesvig i alle Maader at staae ved Siden ad Tydsken. - Herpaa maa jeg nu svare, at vor Ret at hæve Dansken i Slesvig til den Ligevægt, den vi, ved mange uheldige Omstændigheder, og tildeels ved stor Forsømmelse og Ligegyldighed fra vor Side, har tabt, for det bør der giøres alt mueligt, og kan der allerede giøres meget, blot ved at løse de Baand, som vi selv har knyttet, og giøre det godt, som vi selv har gjort galt, saa Slesvig virkelig faaer halvdansk og halvtydsk Bestyrelse, Retspleie, Kirke, Skole og Folkeraad «.

Allerede dette afsnit af talen må Goldschmidt have læst med levende interesse; det rummede jo en hel del af hans egne forslag om, hvad der burde gå forud for grundlov og valgret. Det næste må have glædet ham endnu mere, for nu fortsætter Grundtvig: 
"Men kan vi saa ikke nok med det Samme paa en Maade indlemme Hertugdømmet Slesvig i Kongeriget Danmark, uden at bryde os om, enten hvad Holsteen eller det store Tydskland, eller hvad Slesvig selv siger dertil? Ja, her i »Casino« skal de fleste Herrer i Lørdags Aftes have sagt, jo, det lod sig nok giøre - vi behøve ikke at kalde det Krig, men desuagtet vilde dog vist baade Holsteen og hele Tydskland tage det for en Krigs-Erklæring, og jeg maatte ikke blot kalde det Krig, men en meget uretfardig, urimelig og ulyksalig Krig med Hertugdømmet Slesvig, hvor vi umueligt kunde vinde noget, meget mueligt miste Alt hvad et Folk har at tabe«.

Grundtvigs frygt kommer dog ikke af, at han er en kryster, omend et "saa lille og udsat Rige som Danmark, tit af Klogskab maa spille en Krysters Rolle«. Det skyldes, »at jeg er mere frisindet end de Fleste. - Men vil man uden Slesvigs Minde ... lægge eller smække det til Kongeriget Danmark, da siger jeg: det gaaer vist aldrig godt. - Om jeg derfor ogsaa havde Magt til, mod Slesvigernes Villie, med denne min Haand at ramme Kongeriget Danmarks Grænsepæle saa dybt ned langs Eideren, at Slesvig-Holstenerne med alle deres Venner i Romer-Riget skulde lade være at rokke dem, saa vilde jeg dog aldrig giøre det, især af den gyldige Grund, at det aldrig kunde nytte Danmark, men maatte umaadelig skade Danmark, at pine endeel Tydsk og Utydsk ind i sig, der netop da bestemt aldrig blev Dansk, saalidt som Irsk nogensinde bliver Engelsk, vilde derfor altid give os Splid, aldrig forøge, men altid svække Danmarks samlede Styrke«.

Skulle Goldschmidt imidlertid på grund af denne skarpe indsigelse mod de Nationalliberales i »Casino« proklamerede »Ejderstatspolitik « have ventet i Grundtvig at finde en forbundsfælle, blev han snart overbevist om sin fejltagelse. De var begge modstandere af en tvungen indlemmelse af Slesvig og ingen af dem troede på nytten af en daniseringspolitik, men længere rakte enigheden ikke. Derom fik Goldschmidt klar besked i Grundtvigs næste store artikel i »Danskeren« nr. 8, hvor det hedder:

"Det vilde være fordærveligt at ville sammensmedet en saa kaldt Helstat af Kongeriget Danmark og det indtil Raseri ramtydske Slesvig Holsten«. Oprøret er nu begyndt derovre, og et saadant oprør var nødvendigt, for at »Danmark og Danskheden skulde frelses; thi et Folks Modersmaal og dets hele Eiendommelighed er kun een Smeltning, saa det lader sig ei ved nogen Konst adskille« - - 
"Selv nu er man jo i Kjøbenhavn saa opsat paa hele Slesvigs saakaldte eller ikke saakaldte Indlemmelse i Kongeriget Danmark, at jeg kun har et meget svagt Haab om, at man vil lade den ulykkelige Grille fare, med mindre Tydskerne nøder os dertil«. Derfor bør københavnerne og vore ministre "aldrig mere tænke paa det fortydskede, forbitrede Syd-Slesvigs Indlemmelse i Kongeriget«. Vi skal stå fast på vore egne enemærker, og »Folket maae blive sig selv sin medfødte Art og Natur og sit Modersmaal tro «. ${ }^{15}$

Goldschmidt modtog det konkurrerende tidsskrift ret velvilligt og anmeldte allerede den 1. april »Danskeren«, dog ikke uden bekymring for, hvad Grundtvigs stærke fremhævelse af Danskhed og Nationalitet vel kunne føre til: „Gamle Grundtvig har i disse Dage begyndt et Ugeblad »Danskeren«, og gjentager her sin gamle Yndlingssætning, at Ingen kan være ægte Dansk og have virkelig dansk Følelse, naar han er af fremmed Herkomst og ikke oprindelig Dansk. Hvo er oprindelig Dansk? Om hvem kan det med utvetydig Sikkerhed bevises? Saaledes er forhen blevet spurgt; nu kommer et nyt Spørgsmaal som Indvending mod Grundtvig og dem, der hemmelig dele hans Anskuelser. Ere vi Andre, som elske Danmark, som tale og skrive dets Sprog reent, som have stillet vort Liv til Statens Tjeneste, redningsløst stillede udenfor den danske $\mathrm{Na}$ tionalitet, altsaa fædrelandsløse, fordi der er et udansk sch i vort Navn, eller fordi vi have mørkt Haar og mørke Øine? Om vi falde for Danmark, om vort Hjerteblod flyder, skal da dette Hjerteblod ikke kunne opveie det ulykkelige sch? - Herregud, hvor Folk kunne være ubarmhjertige i deres Fædrelandskærlighed «. ${ }^{16}$

Disse let bedrøvede ord, der - utilsigtet - lyder som et ekko af jøden Shylocks berømte monolog i "Købmanden i Venedig « ${ }^{17}$ synes ikke at have gjort indtryk på Grundtvig. I det følgende nr. af »Nord og Syd « fortsætter Goldschmidt sin anmeldelse af det nye blad. »Af Grundtvigs Ugeblad »Danskeren« er det 2det Nr. udkommet. Om jeg i min Anmeldelse af det første Nr. ikke skulde have forstaaet ham rigtig, da vil jeg gjøre Undskyldning; men $\mathrm{i}$ dette Nr. træder med utvetydig Klarhed følgende Tanke frem: Slesvig er os vigtig, og vi maae staae Last og Brast med vore danske Brødre der. Men hvad først og fremmest er vigtigt, er at gjøre Landet indtil Kongeaaen aldeles dansk, og navnlig trænge vi da her i Kjøbenhavn haardt til at »blæse ad tydsk Sprog, tydsk Lærdom, tydsk Historie, Poesi og Philosophi $\kappa^{18}$ I een Henseende er 
Opfyldelsen af dette Ønske aldeles umulig; vi kunne jo ikke afslutte os fra den Deel af Civilisationen, som Tyskland repræsenterer, og betragte Alt, hvad der gjennem dets Sprog vindes for Verdensbevidstheden, som dødt og magtesløst. Vi ere nok Danske, men ogsaa Mennesker. Derimod kunde der vistnok vaages over, at det danske Sprog blev mindre fordærvet under Paavirkning af Udlandets Literatur «. Goldschmidt slutter forsonligt med at erindre om, at netop "Grundtvig har krævet en bedre Opdragelse i Skole og Familie ... den gamle Skjald maae nu tage tiltakke med den tarvelige Trøst, at han blandt Yngre har vundet flere Tilhængere, end han maaskee troer, og der, hvor han mindst havde ventet det «. ${ }^{19}$

\section{IV}

Imidlertid gik den slesvigske krig sin gang, og den var som bekendt ikke gunstig for Danmark. Efter den danske hærs nederlag ved Slesvig 23/4 og Jyllands rømning var der indledt våbenstilstand, og nu havde et dybt mismod afløst den festlige stemning fra martsdagene. England forsøgte mægling, men det var nu klart, at ingen af stormagterne ville gå i krig for Danmarks skyld, og vinteren sled sig hen, mens kongen og ministeriet var uenige om, hvorvidt man skulle forsøge at få gennemført en deling af Slesvig. Vi lytter igen til Goldschmidts Dagbog. Under 6. januar 1849 skriver han: "Det er ... en højst besynderlig Polemik, der føres hos os om Slesvig. Et Parti erklærer det som sin Anskuelse, som sin Fordring, at vi erholde hele Slesvig, et andet, at vi nøies med en Deel deraf; men ingen af dem angiver rimelige Udsigter, tilstrækkelige Midler til at naae det Ønskelige, det, som er Nationen tjenligst. Og imidlertid føres Fredsunderhandlingerne efter en Krig, som ikke har været heldig, og hvis ikke næsten vidunderlige Omstændigheder indtræde, er det altsaa rimeligt, at Freden ikke skaffer os det Ønskelige. Under disse Omstændigheder er gamle Grundtvig optraadt med den inconsequenteste Consequens (han forstaaer vel saa meget »Pluddervælsk «, at vi ikke behøver at oversætte det Uoversættelige), han har i Rigsforsamlingen forebragt det Ønske, forlangt det udtalt, at alle Fredsunderhandlinger skulle afbrydes og Krigen begyndes af al Kraft for at erhverve hele Slesvig. Vi kalde det consequent, fordi det er en tankerigtig Følge af Omstændighederne: Da Freden formeentlig ikke kan være os gunstig efter den daarlige Krig, saa lader os føre en bedre og først da søge Fre- 
den; Diplomatien kan let overliste og narre os. De mindre poetiske og mere beregnende Mænd i Rigsforsamlingen afviste Forslaget, og det vilde da i alt Fald ikke have været »constitutionelt « handlet af Forsamlingen at optræde som Grundtvig vilde, og foreskrive Regeringen Love, dertil var den hverken $\mathrm{i}$ den ene eller anden Henseende "competent .

Men hvorfor føres Fredsunderhandlingerne? For en Forms Skyld, for at vore Diplomater kunne have noget at bestille indtil Marts? Eller for at Freden kan komme og alle Parter misfornøiede finde sig i den og kaste Skylden paa Ministrene? Grundtvig vil have »reent Bord «, og utaalmodig, uden egoistiske Bitanker, kaste Tærningerne, »det briste eller bære!« - Men inconsequent er det paa den anden Side i den mest Grundtvigske Grad. Utallige Gange har han i Skrift og Tale erklæret sig for det danske Rige, villet have en reen dansk Stat, hvori intetsomhelst Tydsk turde aande. Hvad vil han nu med den tydske Deel af Slesvig? Hans Inconsequens bliver kun overgaaet af de Journalister, der iaften ikke have Ord nok til at vise Forslagets Urimelighed og Daarskab, og som i Marts stillede netop det samme, fik det sat igennem og forkastede alle Underhandlinger. ${ }^{20}$ Man har Lov at blive klog af Erfaring; men saa skulde man ikke saa dristig løfte Øinene mod Himlen og sige: »Herre, jeg takker dig, at jeg ikke er som denne Tolder! « ${ }^{21}$

Grundtvig finder fremdeles ingen anledning til at svare Goldschmidt. Denne tager da ordet igen i sin Dagbog for 11. marts, hvor han prøver at klargøre forholdet mellem Grundtvigs lyriskmystiske fædrelandsfølelse og sin egen ikke mindre oprigtige, men mere nøgterne nationale holdning:

"Der bestaaer her i Byen en »Dansk Forening «, stiftet af Dhrr. Grundtvig, Flor, en Mængde Rigsdagsmænd o.s.v., og hvis Formaal er at "holde over Danmarks og Danskhedens Ret og Ære« - "at hævde ei blot Danmarks Grændser, men ogsaa det danske Sind, den danske Tænkemaade og disses troe Tolk det danske Modersmaal«. I disse Dage har Foreningen udstedt et Opraab, hvori den opfordrer Folket til overalt at danne lignende Foreninger, der skulle træde i Forbindelse med det kjøbenhavnske Moderselskab «. Disse foreninger synes kun at have "et Gemytsformaal, deres Forhandlinger ville have til Hensigt at styrke Medlemmernes kjærlige Følelser, de ville blive et Slags Kjærlighedsmaaltider noget lig dem, som de første christne Menigheder holdt, kun med den Forskjel, at 
Nationaliteten træder stærkere frem end Religionen. Der er naturligvis ikke det ringeste Onde at sige om det fædrelandske Sind, der har lagt en saadan Plan ... men vi frygte, at man vil opnaae noget andet end det man tilsigter. De gamle Danske vare danske uden at stifte Foreninger for Danskheden, og netop deri bestod deres Danskhed. En Forening af Mennesker, der skulle tænke paa at være danske, bliver reflecteret-danske, dvs. sentimentale. - Efter vor Formening bliver det danske Sind hævdet ved sunde Gjerninger og det danske Modersmaal ved sund Kritik. De kraftigste Folkeslag have altid været dem, der droge det nationale Aandedrag dybt uden at tænke derover; men det er et slemt Tegn, naar man begynder at lytte til sine Lunger «.22

Goldschmidt, der samtidig var blevet angrebet af forfatteren $H$. E. Schack i hans lille ugeblad "1848 « som en digter, der burde holde sig fra politik, fandt nu tiden inde til at tale rent ud af posen. I oktober 1849 skrev han i »Nord og Syd« under titlen »NATIONAL « en artikel, der var et opgør med Schack, som med forblommede ord havde mistænkeliggjort Goldschmidts nationale sindelag, og med Grundtvig.

"Skal det at være "national « betyde, at man hører til en Menighed, der har sit Alter og sin Guddom, sin Tro og sine Mysterier, som Uvedkommende vel kan see paa og respectere, men hvis sande Inderlighed han ikke føler ... er dette at være "national «, og høre vi i denne Betydning til de Uvedkommende, de Unationale? Velan, vi modtage Kampen her, men vi spørge da: Hvor er Eders Mysterier, som vi ikke kjende, hvor er Eders Alter, hvor vi ikke bede, hvor ere Eders Offre, i hvilke vi ikke deeltage? Det Sprog, der omslutter Eder som Menighed, lader os ikke udenfor! I have dem, der værne det bedre, men Ingen, der værner det kjærligere end vi; I have Digtere, der skrive smukkere, end vi tør tænke paa, men Ingen, der fatter Digtene bedre end vi; Eders Fortids Digte, Sagnene, Sagaerne og Viserne, ere blandt de faa Ting, som have kaldt os hjem fra Syden, fra Tilbud om Livsophold og Velvære - ja, »hjem«, her er vort $\mathrm{Hjem}$, vi have intet andet, Ingen af Eder kan vise os bort som Uvedkommende«. Han anfører digtere der som Baggesen og Oehlenschlæger skrev digte både på dansk og tysk, han tilbyder at fordanske sit eget Navn "hvis det kan hjælpe til en Forsoning. Idet vi forsvare os mod en "national « Beskyldning, synes det os næsten, at denne Nationalitet er latterlig og falsk. Vi ville hellere 
selv ganske kort sige Eder, hvad det er at være rigtig "national«:

Det bestaaer $\mathrm{i}$ at ville et Ideal og lukke Øinene for Virkeligheden, at ønske det Bedste og foranledige Ting, der lede til det Værste, at tilbyde sig som Veiviser, gaae ufortrødent fremad, føre Folk ud i et Morads og beskylde den for "Hjerteløshed«, som sagde, at der var et Morads.

"National « er den, der har et Exemplar af det mellem Kronerne Danmark og Preussen vedtagne Fredsgrundlag liggende for sig, bruger det til Fidibus for at tænde sin Opiumspibe, hyller sig og Folket ind i Opiumsdampen og derved fremtryller yndige Billeder, for hvilke Folket er ham taknemligt, »han er dog saa god!«. »Unational« er den, der vækker Opiumsdrømmeren og bringer de deilige Billeder til at forsvinde; "unational « er den, der viser Folket Virkeligheden og beder det samle al sin Kraft, al sin Kløgt, al sin Selvbeherskelse ligeoverfor den, thi Virkeligheden er som en Creditor, der ikke opgiver sit Krav, fordi han faaer Grovheder. - Men er dette virkelig unationalt, saa tilstaae vi, at vi gjøre os den største Umage for at være det.

Til denne Stat ... til dette Hjem, hvis Fred og Hyggelighed ogsaa bliver vor, have vi kun at sige og gjentage: Vi Allesammen ere ikke Guds Udvalgte meer end de andre nulevende Mennesker; Solen staaer ikke stille i Gibeon, og Maanen standser ikke i Ajalons Dal for at lette os vore Kampe og hjælpe os til at ødelægge vore Fjender; der er ikke forjættet os Mere end de andre europæiske Folkeslag og vil ikke blive givet os Mere; hine reiste sig som vi for at opnaae alle Ønsker, og see nu ud over dem, hvad de have lidt, og hvor Meget de have maattet opgive; nogle af dem ligge nedtraadte, blodbestænkte, sønderrevne, dem alle forestaaer en Tid fuld af Anstrængelser, Savn og Farer, dem alle synes en mægtig Finger at have viist, at hvor de troede at finde Lykken, var den dog ikke at finde. Lad dette, om ikke forringe Agtelsen for vore egne Bestræbelser og Kampe, saa dog bevirke, at vi blive billige $\mathbf{i}$ vore Fordringer til Livet og Virkeligheden ${ }^{23}{ }^{23}$

\section{$\mathrm{V}$}

Goldschmidts forholdsvis venlige omtale af "Danskeren" gav ikke Grundtvig anledning til at gøre gengæld ved at angive sin holdning til »Nord og Syd«. Men Goldschmidts af de schweiziske 
indtryk bestemte forhold til Helstaten og hans forsøg på en nøgtern vurdering af de vanskelige politiske udsigter må have ærgret Grundtvig. Denne artikel om begrebet »national« kaldte ham frem; og nu er det en vred mand, der svinger Skræp med begge hænder. Tirret af det slesvig-holstenske oprør vil Grundtvig nu rykke al hjemlig tyskhed op med rode, nu skal enhver "fremmed" eller »udansk « passe på, hvad han siger. Danmark er stedt i den yderste nød og kun den rene danskhed kan frelse folket, hedder det $\mathrm{i}$ "Danskeren« nr. $44 .^{24}$

»Udgiveren af Ugeskriftet »Nord og Syd«, Hr. Goldschmidt, har alt længe udæsket Folkeligheden i det Land, hvor han fandt saa megen Gæstfrihed, at han upaatalt kan bære sig ad, "som han var hjemme «, og da han udæsker Danskheden paa en langt smukkere og taaleligere Maade, end vi er vant til hos vore Giæster, saa vil han, haaber jeg, saameget mindre fortørnes over, at ieg paa Danskhedens Vegne baade modtager og besvarer hans Udæskninger for at bryde en Landse med ham «, skønt - påstår Grundtvig - „Danskeren « hidtil ganske har undgået hans opmærksomhed. Men dermed er den urbane tone forbi. Nu skal læserne have en forestilling om »vor Modstander og hans Udæskning «. Og nu glemmer Grundtvig helt, at han allerede i flyveskriftet »Til Fædernelandet, om dets Tarv og Fare« (1813) under den første jødefeide havde fordømt skriget mod iøderne, skønt han endnu ikke ville give dem fulde borgerrettigheder. ${ }^{25}$ Uanset at han i »Mands Minde « $(1838)^{26}$ måtte "ytre mit dybe Mishag med det hele Skrig mod det ypperste og giennem snart to Aartusinder ulykkeligste Folk paa Jorden «, om hvilket »Historien lærer mig, at de er til Velsignelse eller Forbandelse eftersom de behandles «, belærer han nu Goldschmidt om, at han "folkelig talt er en Giæst iblandt os «, og at han legemligt og åndeligt tilhører »dette mærkværdige iødiske Folk«. Ganske vist skriver han "Dansk langt bedre end de fleste saakaldte Danske Forfattere«; og om statssager skriver han med langt bedre forstand på de virkelige forhold end både »Fædrelandet« og »Kiøbenhavnsposten«. Men han har fået »den Grille at ville giælde for en fuldkommen Dansker, og fortæller enhver af os, der paastaaer, vi har en Danskhed, han fattes, at den kun bestaaer $\mathrm{i}$ »at ville et Ideal og lukke Øinene for Virkeligheden ... at tilbyde sig som Veiviser, gaae ufortrøden fremad, føre Folket ud i et Morads, og beskylde den for Hierteløshed, som sagde, at der var et Morads«.« 
Og så fortsætter Grundtvig: »See, dette er baade for grovt og for galt, især af en Tænker, som godt veed, hvad vi meener og kan selv udtrykke det«, nemlig med sit spørgsmål om, hvad »national« betyder. »Hvor er Eders Mysterier . . . hvor er Eders Altre ... hvor er Eders Offere osv.?

"Velan da, jeg paastaaer ganske rigtig om Danskheden og Nordiskheden, at den, som enhver ægte Folkelighed, har sine Hemmeligheder (Mysterier) og sine Altre, som en Fremmed vel kan betragte som han veed, det gamle Israel var sammensmeltet med sit Modersmaal og saae i Jerusalem sin høieste Glæde«. Og skulle han have tabt denne følelse, så kan han endnu mindre fatte, "hvad vi føler og bære Agtelse for, men hvis sande Inderlighed han ikke føler, fordi han ikke hører til denne Folke-Menighed, har hverken Aand eller Hjerte tilfælles med den«.

$\mathrm{Da}$ nu Hr. Goldschmidt hører til et folk, som ulykkeligvis har mistet både modersmål og fædreland, føler han sikkert det ubodelige tab heraf - og »hvor umueligt det falder ham saaledes at sammensmelte med det Danske Tungemaal og opoffre alt for Danmark, for Danmark og Danskheden. Det er usømmeligt af ham at tale om »Morads«, og han »bryder Giæstevenskabet og misbruger baade vort Fæderneland og vort Modersmaal ved at raade til dets Skade, idet han beleer vor Frygt for at være sammenkobblede med Tyskland og høre tyske Taler paa vor Danske Rigsdag «.

Så mildner Grundtvig igen den hårde tone en smule. »Jeg tror slet ikke, Hr. Goldschmidt mener det ilde med os«, ja, han har endda lidt Forkærlighed for "deiligst Vang og Vænge«, hvor han kom til Verden, for det "yndige Tungemaal, der alt i Barndommen kildrede hans Øre - siger den ene sydsjællænder til den anden - »men jeg kan see, at han betragter det altsammen ikke med en Dannemands eller ægte Nordbo's, men med en Verdensmands Øine, hvem det dog igrunden er ligegyldigt, om Landet, han boer $i$, hedder Danmark eller Slesvig-Holsten«. Ulykken er, at han betragter sproget kun som et middel til at gøre sig forståelig for andre, han hæver sig over folkeligheden, som et snævert og egenkærligt begreb, der hvis det fik magt, "vilde opløse ikke kun den østerrigske Stat og Svejtser-Forbundet, men spærre Veien for den almindelige Kultur. der, som et Jernbane-Net, skal omspænde hele Verden«. Men dersom dette er hans mening, indvikler han sig i selvmodsigelse, »og saa er vor Trætte jævnet, vi forlanger intet Ja-Broder- 
skab af de Fremmede paa vore Enemærker, men kun Fredelighed og den sunde Sands at stikke Fingeren i Jorden og lugte, hvor man er«.

Derefter skærpes tonen igen, og til afslutning får Goldschmidt et ubarmhjertigt alvorsord med: "Jeg kan godt forstaae, at i Danmark, hvor det Fremmede længe har været vant til at herske og at blive alt det Egne foretrukket, ja, hvor hele Dannelsen længe var fremmed og de Udannede foragtedes, her maae det falde baade Hr. Goldschmidt og mange andre ligesaa uventet som ubehageligt at blive saaledes tiltalt og henvist til den udannede Almue, for at lære, hvad der er Dansk og herefter skal herske i Landet; men Hr. Goldschmidt er klog nok til at kunne forstaae, at det er ægte Dansk i Danmark, saa hvem der ikke kan finde sig deri, er udansk og lader det komme derpaa an, om han og de andre Fremmede eller det Danske Folk skal seire i Danmark. Dette, at vi, vistnok endnu kun meget faae Deeltagere i Tidens forroste Dannelse, som vil og tør vedkiende os Danskheden og paatale dens historiske Ret til at raade paa sine Enemærker, at vi, skiøndt vi har Blækstrømme og Mundsveir imod os, dog har et Folk, ligesaa stort som hele Landet, i Ryggen, og at dette lille, men kiække og velbegavede Danske Folk vil findes ligesaa farligt at bides med paa dets indvendige som paa dets udvendige Enemærker, det er, hvad jeg herved onskede at indskærpe Hr. Goldschmidt og alle Ligetænkende i Danmark!«

Det var en banstråle, og den ramte Goldschmidt i hjertet. Fra barndommen havde han ofte følte sig henvist til Ghettoen. Men på Skamlingsbanken, hvor han og Grundtvig første gang mødtes $\mathrm{i}$ 1844, havde han på sit forpinte råb: »Jeg er en jøde, hvad vil jeg iblandt jer? « mødt venlige tilråb og udstrakte hænder. Nu var det den store Skamlingsbanketaler, der stod frem og raabte: $\gg D u$ er en Jøde! Hvad vil du iblandt os? « Det sved, og jævnlig vendte han tilbage dertil i sine reflektioner i »Nord og Syd« de følgende år.

Man kan undre sig over, at Goldschmidt ikke i sit svar på denne hårde tiltale, der ligesom satte ham udenfor det danske fællesskab, greb tilbage til Grundtvigs digt »Folkeligheden«, der stod i »Danskeren « $\mathrm{i}$ august 1848 "Folkeligt skal alt nu være ${ }^{27}$ Nok tales der i dette fyndige digt om "Byrd og Blod «, men kernen er dog dette vers: 
Til et Folk de alle høre,

som sig regner selv dertil, har for Modersmaalet Øre, har for Fædrelandet Ild. -

Goldschmidt måtte selv føle, at han opfyldte alle tre betingelser. Det er vel derfor hans svar på dette angreb er behersket og bedrøvet, med et anstrøg af humor, da han indledningsvis drøfter Grundtvigs tilbud om at »bryde en Landse med ham«. »Sæt, at jeg noget ublidt løftede Hr. Grundtvig af Sadlen, saa var Sagen ikke dermed afgjort til min Fordeel, saa kunde Hr. Grundtvig og hans Ligesindede komme og spørge, hvorledes jeg, den Fremmede, »Jøden«, havde turdet vove at kaste en dansk Præst og dansk Digter og dansk Historiker og dansk Rigsdagsmand ned af hans høie Hest, saa at Folk uvilkaarlig kom til at lee ad ham, hvorved jeg tilsidesatte Respekten, ja jeg burde maaskee endog af pligtmæssig Ydmyghed have tiet stille«. Men Grundtvig har forbundsfæller, de har næsten alle anvendt de samme våben imod ham, de ville alle spærre ham inde $\mathrm{i}$ » Journalistikens Ghetto«. Ved at reducere ham til en æstetisk skribent, hvis arbejder man læser for at fornøje sig, har man villet berøve hans ord deres livskraft; man kan ikke stole på ham, når de angår folkets dybeste anliggender. Således var det i "Corsartiden«, sådan er det nu. "Tilsidst skulle mine Ord blot være Klingklang for Dagdrivere«.

Lykkeligvis føler han bag Grundtvigs hårde ord en sympati, $i$ de mange vredesudbrud blander sig »uvilkaarlige Velvilliesytringer, - hans indgroede Fordomme ligge og kjæmpe med den lyse Forstandighed og Hjertensgodhed; men behøver blot at gjøre ganske lidet for at hjælpe hans gode Natur til at seire«.

Taknemlig er han for Grundtvigs ord, at »Goldschmidt skriver Dansk langt bedre end de fleste saakaldte Danske Skribenter«. Den ros anvender han til $i$ et stilfærdigt selvforsvar at fremhæve sin overbevisning om den organiske sammenhæng mellem mennesket og stilen. "Det lader sig ikke miskjende, at Sproget som Udtrykket af det, der bevæger Menneskets Indre, som Frembæreren af hans Tanker, er nøie sammenvoxet med hans hele Personlighed, at det ikke blot karakteriserer Mennesket udefter, men at det ogsaa, idet det virker tilbage paa hans Indre, paatrykker ham det nationale Præg, som han ikke kan unddrage sig . $^{28}$ 
Morsomt tænker han sig, at dersom Grundtvig virkelig havde tilegnet sig det hebraiske sprog, ville han sikkert have travlt med at udrydde Amalekitter og genopbygge Zions tempel, i stedet for »med Træsværdet og Skinken at spærre Jøden Veien til Tournerpladsen«. Men sådan er det nu, og på den måde berøvede man Goldschmidts kloge ord og klare tanker deres virkning. ${ }^{29}$

Trods den forsonlige tone i svaret, viser hans selvopgør i 1853 citeret ovenfor - hvor hårdt Grundtvigs banlysning ramte ham. På grundlag af sin varme kærlighed til Danmark og det danske sprog og ud fra sin levende føling med aktuelle strømninger i europæisk politik, brændte han efter at tage del i den ivrige meningsudveksling, som nu var brudt løs. I stedet havde han fået at vide, at han burde holde sin mund.

Alligevel ville man tage fejl, om man betegnede Grundtvigs holdning $i$ dette opgør med det $i$ en senere tid gængse udtryk antisemitisme. Sådan har Goldschmidt oplevet det. Men for Grundtvig blev denne debat med den begavede redaktør af "Nord og Syd" anledning til dybere klaring af, hvad han egentlig mente med sin tale om folkelighed. Under den kamp for tilværelsen, som oprøret i Slesvig-Holsten havde indviklet Danmark i, rettede Grundtvig et afgørende slag mod den akademiske overklassekultur, der $i$ hans øjne kun var en efterabning af fremmede moder, der ikke tillod det oprindeligt danske væsen at komme til udtryk. Det var en farlig svækkelse, og derfor måtte alle fremmede unoder fjernes som svamp i det ellers sunde træ. $\mathrm{Og}$ når han peger på jødens tabte folkelighed, har det sin årsag $i$, at hans eget begreb om folkelighed jo på sin vis var af jødisk, religiøs art. (I forordet til »Nyaarsmorgen«, 1824, kaldes Danmark »Historiens Palæstina«; senere dukker det ofte latterliggjorte udtryk »det lille udvalgte folk« op). Derfor må »tyskeriet« under enhver form stemples og jages ud; derfor tåler han heller ikke den kølige, verdensborgerlige tone i Goldschmidts set med vore øjne både kloge og fremsynede betragtninger.

\section{VI}

Goldschmidt selv bevarede et ironisk forhold til Grundtvig, det fremgår af de spredte bemærkninger om og til »ærværdige $\mathrm{Hr}$. Pastor Grundtvig « eller »Rigsdagsmanden Grundtvig« som jævnlig findes i de politiske dagbøger $\mathrm{i}$ »Nord og Syd«. Han drillede 
Grundtvig for hans næsten fanatiske nationalisme og morede sig over historien om tyven Niels Jørgensen, som under oprøret flygtede fra fængslet i Rendsborg og søgte over Kongeåen til det egentlige Danmark, men til Grundtvigs dybe forargelse blev mødt med politi og arrest i stedet for ros for sit gode danske sindelag! $!^{30}$

Allerede 1848 havde Goldschmidt ytret et syn på nationaliteten, som ikke faldt i god jord, hverken hos de Nationalliberale eller hos Grundtvigs meningsfæller: »Vi forstaae ikke den ængstelige Omhu, man har for Nationaliteten, som om den var noget Konstigt, og maatte tages ind om Vinteren ligesom Drivhusplanten. See engang den jødiske Nationalitet, hvor den har holdt sig, uagtet man har nedtrampet og sønderslidt den! Ingen Nationalitet gaaer under, naar den faaer det Næringstof, den behøver «. ${ }^{31}$

Og da Treårskrigen var afsluttet, lod Goldschmidt sig ikke forvirre af den glade »Dansken har Sejer vundet«-stemning. Han opfattede klart den ustabile stilling, hvori Danmark fremdeles befandt sig og som måtte ende i et nyt og langt farligere opgør. Han frygtede stadig den mangel på virkelighedssans, som prægede de grundtvigske »Conventikler eller Samfundsmøder, hvor man sang om Uffe hiin Spage, om Modersmaalets Sødhed osv, og havde en Slags hemmelig Cultus, som Politikerne smilte ad, eller som de fandt skadelig, fordi Folket ved disse dunkle Sympathier blev holdt i blind Afhængighed af Skjoldungestammen « ${ }^{32}$

"De Nationale som saadanne havde og har ingen Religion. De kalde sig i det daglige Liv Christne, men deres Nationalitets Guddomme ere Thor, Odin osv., poetiske Figurer, der ere istand til at fylde Sindet med en Slags Begeistring, hvorpaa man dog ikke selv troer for Alvor. En af de Nationales Præster, en virkelig Præst, erklærede jo endog, at Christendommen ikke havde Noget at bestille med de foreliggende store Opgaver - det daglige Livs, Familiens, Arnens Gud var suspenderet «. ${ }^{33}$

»Sæt, at saadanne halv- eller helgamle Folk som Clausen, Grundtvig, Monrad, Hall, Lehmann osv. i rette Tid havde været saa fornuftige, som idetmindste nogle af dem $\mathrm{i}$ den seneste Tid have forsikkret om dem selv, at de ere! Sæt, at de fra Først af havde erkiendt Betingelserne for Danmarks Existens, Helstatens Nødvendighed, og stræbt efter at reformere den førmartslige Helstat, søndre Delene, bringe Folket saa megen Frihed som mulig hvis de havde erkiendt Nødvendigheden og kommet den imøde, ja, 
saa havde de vel tabt lidt i Popularitet, men reddet megen Frihed; de vilde da selv have kunnet udføre Gjerningen, de vilde selv have kunnet regere Slesvig og ordnet Hertugdømmets Forfatning!

Istedetfor have de blot bidraget til, at den kostbare Tid gik tabt; der blev ikke arbeidet, mens det var lyst, og saa kom det franske Statscoup af 2den December 1851«. (Napoleon III, af hvem Goldschmidt ikke ventede noget godt, hverken for Europas fred eller Danmarks sag). ${ }^{34}$

Der var dog en af de såkaldte "Martsministre«, som Goldschmidt vedblev at omtale med sympati og beundring. Det var $A$.F.Tscherning. Denne konservative realpolitiker blev allerede i løbet af året 1848 overbevist om Ejderstatstankens uigennemførlighed og kom derved i modsætning til sine nationalliberale kolleger. Ligesom Goldschmidt argumenterede han for en føderativ statsordning, "hvor de enkelte Statsdele indenfor Monarkiet skulde have den størst mulige Selvstændighed «. Som Goldschmidt fremhævede han Schweiz og Nordamerika som de forbilleder, der bedst ville kunne passe for en fornyelse af den danske Helstat. Det var også hans overbevisning, at friheden bedst kunne beskyttes, dersom grundloven blev forankret "som en Kantonalforfatning i en føderativ Stat $«{ }^{35}$ Han blev da også ligesom Goldschmidt betegnet som en mand blottet for al fædrelandsfølelse. Men både Tscherning og Goldschmidt var enegængere, "Løsgængere«, og det kom ikke til noget nærmere samarbejde mellem dem. Men i "Nord og Syd * skrev Goldschmidt senere: "Af alle de Ord, der er blevet udtalt paa Rigsdagen, er der ingen, der har glædet mig som Tschernings «. ${ }^{36}$

For Goldschmidt som politisk skribent var ulykken den, at han bl.a. på grund af sine stærke indtryk af den sunde schweiziske forbundsstat med de mange frugtbare indre modsætninger havde gjort sig til talsmand for Helstaten, hvis åndelige rigdom han med sin kærlighed til tysk humanistisk kultur selv havde oplevet. Men det var en tabt sag, og skønt hans forudsigelser om de ulykker der ville følge, om Danmark opgav sin kamp for at holde det gamle monarki sammen på et nyt grundlag, gik i opfyldelse, var og blev han en ensom røst, en efterkommer af Kassandra, hin ulykkelige kongedatter fra Troja, hvem Apollon skænkede spådomsgaven, med den tilføjelse, at hun nok skulle tale sandt, men aldrig ville blive troet.

Hans talrige advarsler mod de skiftende ministeriers skiftende holdning til Slesvig-Holsten og det hastigt voksende Preussen, og 
hans mistillid til de skandinaviske drømmerier, som redaktøren af „Fædrelandet«, hans bitre modstander, Carl Ploug, levede højt på, blev hverken hørt eller forstået, mens landet, som efter en ubønhørlig skæbne, skred nedad mod katastrofen i 1864, »den ved danskernes grænseløse uforsigtighed fremkaldte danske krig", som den schweiziske historiker Jacob Burckhardt udtrykte det. ${ }^{37}$

En vis bitterhed mod Grundtvig blev tilbage i hans sind. Den kommer til orde i flere artikler, der prøver at forklare læserne hvad Grundtvig mener med sin kirkepolitik og sin forkyndelse af »Troesordet«, og $\mathrm{i}$ en ironisk beskrivelse af indvielsen af Grundtvigs højskole "Marielyst « i 1856. Tydeligst spores den i en dagbogsartikel i »Nord og Syd«, 1855, hvor Goldschmidt skriver: »Vel sandt, Jøderne maa nu tale med om Politik, de ere [efter Grundloven af 5/6 1849] emanciperede, de ere frie. Men de have Frihed til at være enige med de forskjellige Partier, ikke til at være uenige med dem. I første Tilfælde ere de »oplyste Medborgere«, i sidste Tilfælde: kun Jøder, Fremmede, uden Hjertelav. Massen af Jøderne, af hvem man naturligvis ikke kan forlange selvstændig politisk Viden, vil desaarsags fornuftigviis holde med dem, der har Magten ${ }^{38}{ }^{38}$

\section{VII}

Næppe nogen dansk skribent er blevet så skånselsløst angrebet som M. A. Goldschmidt, og både Søren Kierkegaard og Grundtvig er blandt de hårde. Under hans kortvarige og mislykkede forsøg på samarbejde med »Grundejerforeningen« - hvor han stadig fastholdt den lige og almindelige valgret - faldt man over ham fra alle sider. Nutidens offentlige polemik kender heldigvis få eksempler på skældsord som dem pressekollegerne Carl Ploug, C. St. A. Bille, Grüne og forfatteren Fr. Dreier, »den første socialist« anvendte mod ham. Derfor blev det ham en dyb glæde, da en af hans mange norske venner, digteren og landsmålsforkæmperen $A$. $O$. Vinje i sit blad »Andhrimner « med varme og forståelse tog ham i forsvar. »Jeg elsker Goldschmidt, som jeg elsker enhver, hvem jeg skylder en Del af mit aandelige Liv. - Man har i Danmark villet gjøre ham til Partimand; nu bebrejder man ham, at han er brudt ud. Men jeg finder Goldschmidts Storhed i denne hans tilsyneladende Flydenhed. Sandheden er ikke noget fikst og færdigt, man kan pege paa og sige: Se her eller der er det. Det er alene grovslaaede Mennesker, som ville tage Sandheden og putte den i Lom- 
men, der ville trumfe i Bordet og sige: Funtus!« Vinje vender sig fra de mennesker som har alting på det rene og tager parti for at udøve magt over andre. "Man maatte fortvivle over en Stat, som indrømmer politisk og literær Indflydelse til Mennesker, som gjør Aanden til en Pasop, som man efter Behag kan pudse paa Hans eller Ole.« Og han protesterer mod den, der tager patent på »det Nationale«. Nationaliteten er ikke udtømt med navnet Grundtvig; den er noget alt for mangfoldigt til at kunne fanges ind $i$ en bestemt fællestype. En sådan findes nok kun i fantasien. Bag alle Goldschmidts handlinger og de sammensatte og stridige elementer $i$ hans karakter finder Vinje en med sig selv beslægtet evne til klart og skarpt at bedømme virkeligheden, uden sentimentalitet eller højtidelighed. Nerven i denne evne er ironien, »Tvisynet « på norsk, der betegner evnen til at se enhver ting ligesom med et dobbeltsyn, evnen til på en gang at kunne se retten og vrangen på livets væv. Det er dette tvesyn, mener Vinje, der bekræfter Goldschmidts åndelige slægtskab med Holberg og Wessel og i grunden gør ham mere nordisk end f.eks. Grundtvig, der aldeles mangler dette tvesyn. ${ }^{39}$

Det er rammende ord. Som skribent søgte Goldschmidt sandheden i de reale menneskelige forhold. Den sandhed kan aldrig rummes indenfor et enkelt parti, og når man som han ofte er tilbøjelig til at søge sine idealer på den modsatte side af den, hvor man selv befinder sig, duer man ikke som partigænger. Som det hedder om den rige købmand Krog i fortællingen "Ravnen«, en af Goldschmidt bedste: »Krog var ikke en Mand af en saadan Natur, at han, naar han stod under en Partifane, opdagede noget Godt og Smukt under en modsat Fane, længtes derefter og blev blød om Hjertet. En saadan romantisk-upaalidelig Idealisme var fjern fra ham, han saa kun efter Partiets Maal, gjættede det eller fik det at vide, fulgte Førernes Vink, var og blev kaldt: en Mand af Alvor og Troskab $\ll^{40}$

Når det politiske stof i tidsskriftet "Nord og Syd « efter Treårskrigens afslutning i stigende grad viger for digteriske og literære indlæg, især den store roman »Hjemløs«, der som løbende fortælling i 1850'erne bringer Goldschmidts opgør med de Nationalliberale og enkelte af Grundtvigianerne, har sammenstødet med Grundtvig sin store andel heri. Afgørende for hans opgivelse af den politiske journalistik blev dog nok hans møde med den dødsyge tysk-jødiske 
digter Heinrich Heine, hvem Goldschmidt besøgte i Paris i somren 1850. På Heines spørgsmål, hvad han i grunden var, havde Goldschmidt tøvende svaret: „ $\mathrm{O}$, ich bin wohl so eine Art von Poet«. Den syge digter svarede iltert: "Eine Art von Poet? Man ist Poet, oder man ist es nicht! « - De ord tvang ham ind i et selvopgør. "Jeg blev kastet ind i mig selv«, skriver han i de utrykte Erindringer. ${ }^{41}$ "Jeg anlagde mine Modstanderes Kritik paa mig selv og søgte efter deres Berettigelse. Det Æsthetiserende gik bort af min Maade at tænke, føle og skrive paa. Jeg havde en dyb, ofte bitter, i alt Fald styrkende Følelse af, at jeg var sand, at jeg stred for det Rette, saa vidt jeg var i Stand til at see det, og jeg led for det«. Selv hævdede han, nu da han var besluttet på helt at vie sine kræfter til digtningen, at adskillige af de artikler, han dengang skrev: om den rette skandinavisme, om de falske idealer, om flosklerne i det patriotiske væsen, ville, dersom de ikke var blevet begravet under tidens ugunst, give ham mere adkomst til berømmelse end det meste af, hvad man som digter har rost ham for. Et udvalg af Goldschmidts politiske dagbøger og artikler $\mathrm{i}$ »Nord og Syd « ville utvivlsomt kunne læses med interesse i vor tid, hvor dønningerne efter hans og Grundtvigs strid stadig fornemmes.

\section{NOTER OG HENVISNINGER}

M. A. Goldschmidt: Livs Erindringer og Resultater I-II, 1877.

(Ny udgave ved Morten Borup, 1965).

Breve fra og til Meir Goldschmidt I-III, udgivne af Morten Borup 1963. (Breve).

Hans Kyrre: M. Goldschmidt, I-II, 1919 (Kyrre).

Elias Bredsdorff: Goldschmidts »Corsaren«, 1962.

Mogens Brøndsted: Meir Goldschmidt, 1965.

Niels Neergaard: Under Junigrundloven, I-III, 1892 (Neergaard).

Tidsskriftet "Nord og Syd «, 1847-1859 (N.S.).

Ugebladet »Danskeren« 1848-49.

1. Paul V. Rubow: Goldschmidt og Søren Kierkegaard, 1952.

Elias Bredsdorff: Goldschmidts "Corsaren« 1962, s. 91-139.

2. H. V. Gregersen: Laurids Skaus brevveksling med politiske venner i København, 1966. Skrifter udgivne af Historisk Samfund for Sønderjylland nr. 33.

3. Livs Erindringer og Resultater, I, s. 430.

4. N. S. 1848 , 1. s. $97 \mathrm{ff}$.

5. N. S. 1849 , 2. s. $1 \mathrm{ff}$.

6. N. S. 1848 , 1. s. 165 og s. $274 \mathrm{ff}$

7. N. S. 1847 , 1. Dagbog 22/6. 
8. N. S. 1853,6 . Dagbog 7/7, s. 44.

9. N. S. 1847 , 1. s. $113 \mathrm{ff}$.

10. Neergaard I, s. 113 ff.

11. N. S. 1848,1 . s. $317 \mathrm{ff}$.

12. Neergaard, I, s. $95 \mathrm{ff}$.

13. N. S. 1848 , 2. s. $80 \mathrm{ff}$.

14. N. S. 1848 , 1. s. $95 \mathrm{ff}$.

15. Danskeren 1848 , nr. 8 , s. 115 og s. $120 \mathrm{ff}$.

16. N. S. 1848 , 2. s. $224 \mathrm{ff}$.

17. The Merchant of Venice, act III, scene I.

18. Danskeren 1848, nr. 2, s. 31.

19. N. S. 1848 , 2. s. 231-32.

20. G. hentyder til Plougs samtidige artikler i $»$ Fædrelandet .

21. N. S. 1849, 5. Dagbog 6/1, s. 163 ff.

22. N. S. 1849, 6. Dagbog 11/3, s. $234 \mathrm{ff}$.

23. N. S. 1849 , 1. s. 209-215.

24. Danskeren nr. 44, s. 689-697.

25. Erik Møller: Grundtvig som Samtidshistoriker, 1950, s. 99-100.

26. Mands Minde 1838, XLIX, 21/11, s. $473 \mathrm{ff}$.

27. Danskeren 1848, nr. 24, s. 381. Digtet findes i Højskolesangbogen, 14. udg., nr. 431.

28. N. S. 1849 , 1. s. 333 ff.

29. Kyrre I, s. 235.

30. N. S. 1850 , 5. s. $464 \mathrm{ff}$.

31. N. S. 1848 , 1. s. 332 ff.

32. N. S. 1856, 3. Dagbog 1/7, s. 51 .

33. N. S. 1852 , 1. s. $312 \mathrm{ff}$.

34. N. S. 1854 , 4. s. 119.

35. Neergaard I, s. $656 \mathrm{ff}$.

36. Kyrre I, s. 263 ff. N. S. 1852, s. 313.

37. Jacob Burckhardt: Weltgeschichtliche Betrachtungen, udg. 1905.

Se Morten Bredsdorff: J. B. Profetiske Ord, Hasselbalchs kulturbibliotek, bind 143, s. 44 .

38. N. S. 1855 , s. s. 83 ff.

39. Gerhard Gran: A. O. Vinje, 1917. Begrebet Tvesyn har Vilh. Andersen anvendt og uddybet i Henrik Pontoppidan, 1917.

40. M. Goldschmidt: Ravnen, 1867. Poetiske Skrifter 1898, 7. bind, s. 484 ff.

41. Kyrre I, s. $231 \mathrm{ff}$. 